\title{
Suppressive and curative antiplasmodial properties of Nauclea latifolia root extract and fractions against erythrocytic stage of mice-infective chloroquine- sensitive Plasmodium berghei NK-65
}

\begin{tabular}{|c|c|}
\hline \multicolumn{2}{|c|}{$\begin{array}{l}\text { Authors: } \\
\text { Chinwe S. Alaribe }^{1} \\
\text { Akolade R. Oladipupo } \\
\text { Miracle O. Nani }^{1} \text { (D) } \\
\text { Innocent N. Ijeoma } \\
\text { Bolutiwi D. Olanipekun } \\
\text { Herbert A. B. } \text { Coker }^{1} \text { (D) }\end{array}$} \\
\hline \multicolumn{2}{|c|}{$\begin{array}{l}\text { Affiliations: } \\
{ }^{1} \text { Department of } \\
\text { Pharmaceutical Chemistry, } \\
\text { Faculty of Pharmacy, } \\
\text { University of Lagos, Lagos, } \\
\text { Nigeria }\end{array}$} \\
\hline \multicolumn{2}{|c|}{$\begin{array}{l}\text { Corresponding author: } \\
\text { Chinwe Alaribe, } \\
\text { salaribe@unilag.edu.ng }\end{array}$} \\
\hline \multicolumn{2}{|c|}{$\begin{array}{l}\text { Dates: } \\
\text { Received: } 27 \text { May } 2019 \\
\text { Accepted: } 22 \text { May } 2020 \\
\text { Published: } 30 \text { June } 2020\end{array}$} \\
\hline \multicolumn{2}{|c|}{$\begin{array}{l}\text { How to cite this article: } \\
\text { Alaribe, C.S., Oladipupo, A.R., } \\
\text { Nani, M.O., ljeoma, I.N., } \\
\text { Olanipekun, B.D. \& Coker, } \\
\text { H.A.B., 2020, 'Suppressive } \\
\text { and curative antiplasmodial } \\
\text { properties of Nauclea } \\
\text { latifolia root extract and } \\
\text { fractions against erythrocytic } \\
\text { stage of mice-infective } \\
\text { chloroquine-sensitive } \\
\text { Plasmodium berghei NK-65', } \\
\text { Journal of Medicinal Plants } \\
\text { for Economic Development } \\
\text { 4(1), a72. https://doi.org/ } \\
\text { 10.4102/jomped.v4i1.72 }\end{array}$} \\
\hline \multicolumn{2}{|c|}{$\begin{array}{l}\text { Copyright: } \\
\text { (C) 2020. The Authors. } \\
\text { Licensee: AOSIS. This work } \\
\text { is licensed under the } \\
\text { Creative Commons } \\
\text { Attribution License. }\end{array}$} \\
\hline \multicolumn{2}{|l|}{ Read online: } \\
\hline 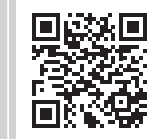 & $\begin{array}{l}\text { Scan this QR } \\
\text { code with your } \\
\text { smart phone or } \\
\text { mobile device } \\
\text { to read online. }\end{array}$ \\
\hline
\end{tabular}

Background: Malaria remains a devastating disease, particularly in the tropics, where it is the highest killer of pregnant women and children under the age of 5 years. Significant efforts and resources have been vested in malaria control and eradication programmes, but the unavailability of malaria vaccine and the emergence of resistance of malaria parasite to existing antimalarial drugs have continued to hamper attempts at controlling or eradicating the disease. This warrants the development of new antimalarial drugs. Nauclea latifolia root is widely applied for malaria treatment in Nigeria.

Aim: This study investigated the antimalarial property of N. latifolia roots.

Setting: N. latifolia roots were collected from Ikwuano, Umuahia, Abia State, Nigeria.

Methods: To extract the bioactive constituents, an aqueous infusion of the plant was prepared and fractionated by solvent-solvent extraction with $n$-hexane, ethyl acetate and butanol, respectively. Antimalarial property was evaluated using suppressive and curative assays in mice infected with chloroquine-sensitive Plasmodium berghei NK-65 strain.

Results: The extract and fractions produced significant suppressive and curative antiplasmodial activities $(p<0.05)$. The aqueous extract and $n$-hexane and butanol fractions gave $85.22 \%$, $84.52 \%$ and $91.32 \%$ chemosuppression, respectively, which were comparable to that of chloroquine used as positive control. The extract and fractions gave considerable curative effects in the range $52.23 \%-77.00 \%$.

Conclusion: These findings indicate that $N$. latifolia roots possess antimalarial property and reflect its ethnomedicinal use for malaria treatment. Thus, N. latifolia roots may be exploited for development of herbal formulations and isolation of novel bioactive compounds for malaria treatment.

Keywords: antimalarial; antiplasmodial; suppressive activity; curative activity; Plasmodium berghei; Nauclea latifolia.

\section{Introduction}

Malaria is a debilitating disease that remains a global health burden despite tremendous efforts towards its control and eradication. The malaria disease continues to wreak havoc to human lives especially in tropical and subtropical regions - particularly in sub-Saharan Africa. World Health Organization (WHO) (2016) reported that in 2015, the global tally of malaria reached 212 million cases and 429000 deaths - about $90 \%$ of these cases and deaths were found in African countries. The disease burden is very alarming in children; malaria, being a major killer of children, takes the life of a child every 2 minutes, which accounts for about $70 \%$ of global malaria deaths (WHO 2016).

Tremendous resources are continuously committed to malaria management, control and eradication. These include chemotherapeutic and environmental interventions such as the use of antimalarial medications, insecticide-treated mosquito nets (ITNs) and indoor residual spraying (IRS). Efforts have also been brought to bear on the development of malaria vaccine. RTS,S/AS01, a recombinant protein-based malaria vaccine, was approved in 2015, by European regulators, as the world's first licensed malaria vaccine and is undergoing pilot trials in chosen countries (Walsh 2015). However, progress in malaria control is repeatedly threatened by the rapid development 
and spread of resistance by plasmodium parasites to currently available antimalarial drugs and by malaria vector to a wide range of insecticides. This has prompted WHO to make a clarion call for the development of novel and more effective antimalarial medicines (WHO 2016).

In this respect, the use of medicinal plants as alternative medicines and sources for the discovery of novel bioactive compounds for drug development has been ongoing for centuries. In fact, some antimalarial drugs in use today were either isolated from plants or developed using the chemical structure of plant's isolates as templates. Two of such drugs are quinine, an alkaloid isolated from a cinchona tree, and artemisinin (qinghaosu), an endoperoxide sesquiterpene lactone isolated from Artemisia annua. These two drugs are now the mainstay of the treatment of severe malaria worldwide (WHO 2012).

Nauclea latifolia Smith (Rubiaceae) is an important medicinal plant that is widespread in the humid tropical rainforest or in savannah woodland zone of West and Central Africa. It is a spreading, evergreen, multi-stemmed shrub or small tree that grows up to an altitude of $200 \mathrm{~m}$ (Balogun et al. 2016). It bears an interesting flower, glabrous rounded ovate leaves and large red ball fruit with long projecting stamens (Duke 2008). Nauclea latifolia is commonly known as African peach or Pin cushion tree. It is called Ubulu inu among the Igbos in the Eastern part of Nigeria; Tafashiya or Marga or Tabashiya or Tuwon biri among the Hausas in the Northern part of Nigeria; Egbesi among the Yorubas in the Western part of Nigeria; Mbom-ibong and Itu among the Ibibios and the Itsekiris in the Southern part of Nigeria (Arise et al. 2012).

Nauclea latifolia has remarkable ethnomedicinal uses, and different parts of the plant are used for preparing remedies for the treatment of various ailments. Decoction of the leaf is used for treating fever, filariasis and chicken pox and for deworming animals (Adebowale et al. 1993). The stem bark is applied as a diuretic, antihelmintic, antipyretic and aphrodisiac (Ademola, Fagbemi \& Idowu 2007). Concoctions, infusions and decoctions of the root are taken as tonic, antipyretic, antidepressant and analgesic and also for the treatment of respiratory illnesses such as tuberculosis, asthma, bronchitis, cough and cold (Abdullahi et al. 2007; Lamidi et al. 1995). The stem bark and roots are also applied for treating jaundice, stomach ache, diarrhoea, dysentery, infertility, hypertension and diabetes (Maitera, Khan \& James 2011; Okwori et al. 2008). The fruit of the plant is used for treating piles, dysentery, colic, emetic and menstrual disorders (Nworgu, Owolabi \& Atomah 2010). The plants have also been reported to be applied for the treatment of gastrointestinal ulcers, leprosy, gonorrhoea, debility, dyspepsia, enteritis, sleeping sickness, prolonged menstrual flow, dental caries and septic mouth (Alaribe et al. 2018; Elujoba 1995; Gidado, Ameh \& Atawodi 2005).

Researches have attested some of the ethnomedicinal uses of N. latifolia. Pharmacological studies have reported the anticonvulsant, anxiolytic and sedative properties of N. latifolia roots decoction (Ngo Bum et al. 2009). Nauclea latifolia has also been reported to have antihypertensive, laxative, antioxidant, antilipidemic, antidiabetic, antimicrobial, antipyretic, antinociceptive, antinflammatory, antiulcerogenic, antisecretory, antiviral, antihelmintic, antitrypanosomal and antidiarrhoeal activities (Ademola et al. 2007; Ademola, Oluwafemi \& Nicole 2014; Akpanabiatu et al. 2005; Alaribe et al. 2018; Arise et al. 2012; Bassey \& Jude 2014; Benoit-Vical et al. 1998; Maikai \& Kobo 2008; Okwori et al. 2008; Owolabi, Nworgu \& Odushu 2010; Onu, Nwiyi \& Erumaka 2015; Taïwe et al. 2011).

The different parts of $N$. latifolia have been documented to contain various chemical constituents. Phytochemical studies reported the presence of alkaloids, flavonoids, phenols, tannins, terpenes, saponins, anthraquinones, reducing sugars, glycosides and cardiac glycosides in decoction of the roots of N. latifolia (Bassey \& Jude 2014; Ngo Bum et al. 2009; Okwori et al. 2008; Taïwe et al. 2011). Alkaloids, saponins, carbohydrate and resins have also been identified in the extracts of $N$. latifolia leaf (Okwori et al. 2008). Indole alkaloids have been found in the heartwood, trunk-bark, stem bark and root of the plant (Brown, Chapple \& Lashford 1977). The presence of monoterpenes in the epicarp of the plant's fruit has also been reported (Abreu \& Pereira 1998).

Aqueous extract of $N$. latifolia roots is widely taken as an alternative medicine for the treatment of malaria in different parts of Nigeria. This study was conducted to assess the veracity of the aforementioned traditional usage of $N$. latifolia roots. Thus, we investigated the suppressive and curative antiplasmodial effects of $N$. latifolia against erythrocytic stage of mice-infective chloroquine (CQ)-sensitive Plasmodium berghei NK-65.

\section{Methodology Collection of plant materials}

Fresh roots of $N$. latifolia were collected from Ikwuano, Umuahia, Abia State. The plant material was identified and authenticated (voucher no.: LH 4016) by Mr Odewo at the Herbarium of the Department of Botany, University of Lagos. The roots were air dried under shade and then ground into fine powder.

\section{Extraction and fractionation}

The powdered material (615 g) was extracted by maceration with $2.5 \mathrm{~L}$ of distilled water for 48 hours at room temperature. The plant extract was lyophilised to obtain a solid mass herein referred to as aqueous root extract of $N$. latifolia (ARNL). A portion (15 g) of ARNL was fractionated by solvent-solvent extraction with $n$-hexane, ethyl acetate and butanol in succession. The fractions were concentrated in vacuo at $40{ }^{\circ} \mathrm{C}$ to afford $n$-hexane root fraction of $N$. latifolia (HRNL), ethyl acetate root fraction of N. latifolia (ERNL) and butanol root fraction of N. latifolia (BLNL). 


\section{Animals and rodent parasite}

Sixty adult Swiss albino mice $(18 \mathrm{~g}-25 \mathrm{~g})$ were obtained from Animal Facility Centre of College of Medicine of the University of Lagos, Nigeria, and used for this study. The animals were acclimatised in experimental animal house for 2 weeks and were fed with standard mice pellet diet and water ad libitum. The experiment was conducted in strict compliance with the internationally accepted principles for laboratory animal use and care as contained in the Health Research Ethics Committee of College of Medicine, University of Lagos guidelines on animal use.

Chloroquine-sensitive P. beighei berghei (NK65 Strain) was sourced from Malaria Drug Research Laboratory, Institute for Advanced Medical Research and Training (IMRAT), College of Medicine, University of Ibadan, Nigeria. The parasites were kept alive by continuous intraperitoneal passage in mice every 4 days (Adzu \& Haruna 2007).

\section{Antiplasmodial studies}

\section{Evaluation of suppressive activity (4-day suppressive test)}

Evaluation of suppressive potentials of $N$. latifolia roots was performed according to the method described by Knight and Peters (1980). The mice were inoculated, intraperitoneally, with standard inoculums of $P$. berghei with $1 \times 10^{7}$ infected erythrocytes on day 0 (D0). After parasite inoculum was confirmed, the animals were randomly divided into six groups (groups 1-6) of five mice each. Groups 1-4 were orally administered $100 \mathrm{mg} / \mathrm{kg}$ ARNL, HRNL, ERNL and butanol root fraction of N. latifolia (BRNL), respectively. Two control groups were maintained: positive control, group 5, was treated with $5 \mathrm{mg} / \mathrm{kg} \mathrm{CQ}$, while the negative control, group 6 , received equivalent amount of distilled water orally. Subsequently, on days 1-3, all the animals were treated accordingly (with the same dose and same route) as on day 0 .

On day 4 of the experiment (D4), blood was collected from the tail vein of each mouse and smeared on to a microscope slide in order to make a thin film (Saidu et al. 2000). The slides were then fixed with methanol, stained with $10 \%$ Giemsa at $\mathrm{pH} 7.2$ for $10 \mathrm{~min}$ to reveal parasitised erythrocytes. Parasitaemia was determined microscopically by counting at least a total of 1000 uninfected and infected erythrocytes from random fields. The percentage parasitaemia was determined as follows:

Percentage parasitaemia $=\frac{\text { No.of infected erythrocytes }}{\text { Total no. of erythrocytes }}$

[Eqn 1]

The percentage suppression of parasitaemia was expressed as mean chemosuppression and this was calculated for each test sample by comparing the parasitaemia in infected (negative) control with those of treated mice. The average percentage suppression was calculated from the following expression:

Average $\%$ suppression $=\frac{A-B}{A} \times 100$ where $A$ is the average percentage parasitaemia in negative control group and $B$ is the average percentage parasitaemia in test group.

\section{Evaluation of schizontocidal activity on established infection (curative or Rane test)}

Evaluation of curative potentials of $N$. latifolia roots was carried out according to the method described by Ryley and Peters (1970). The mice were inoculated, intraperitoneally, with standard inoculums of $P$. berghei with $1 \times 10^{7}$ infected erythrocytes on day 0 (D0). Seventy-two hours later, after the parasite inoculum was confirmed, the animals were randomly divided into six groups (groups 1-6) of five mice each. Groups 1-4 were orally administered $100 \mathrm{mg} / \mathrm{kg}$ ARNL, HRNL, ERNL and BRNL, respectively. Two control groups were maintained: positive control, group 5 , was treated with $5 \mathrm{mg} / \mathrm{kg} \mathrm{CQ}$, while the negative control, group 6, received equivalent amount of distilled water orally. The treatment was carried out once daily for 5 days (D0-D4). Thin blood smears stained with $10 \%$ Giemsa at $\mathrm{pH} 7.2$ for 10 min were prepared from tail blood of each mouse daily for the 5 days to monitor the parasitaemia level.

\section{Statistical analysis}

All values are expressed as mean \pm standard error of mean (SEM). The significance of difference in means between control and treated animals for different parameters was determined by using one-way analysis of variance (ANOVA) and Student's $t$-test on Microsoft Excel 2010® Data Analysis tools. A $p$-value of $<0.05$ was considered statistically significant.

\section{Ethical consideration}

Ethical clearance was obtained from the Health Research Ethics Committee, College of Medicine, University of Lagos (CMUL/HREC/03/18/341, 26 March 2018).

\section{Results}

\section{Results of evaluation of suppressive activity (4-day suppressive test)}

The results of evaluation of suppressive potentials of $N$. latifolia roots are presented in Table 1, which shows the percentage parasitaemia and percentage suppression of

TABLE 1: Suppressive activity of Nauclea latifolia roots extract and fractions against Plasmodium berghei-infected mice (4-day test).

\begin{tabular}{lccc}
\hline Treatment & Dose $(\mathrm{mg} / \mathbf{k g})$ & \% Parasitaemia & \% Suppression \\
\hline Negative control & - & $15.90 \pm 0.36$ & - \\
ARNL & 100 & $2.35 \pm 0.21^{*}$ & 85.22 \\
HRNL & 100 & $1.38 \pm 0.80^{*}$ & 91.32 \\
ERNL & 100 & $5.48 \pm 0.44^{*}$ & $65.53^{* *}$ \\
BRNL & 100 & $2.46 \pm 0.10^{*}$ & 84.52 \\
CQ & 5 & $0^{*}$ & 100.00 \\
\hline
\end{tabular}

ARNL, aqueous root extract of $N$. latifolia; HRNL, $n$-hexane root fraction of $N$. latifolia; ERNL, ethyl acetate root fraction of $N$. latifolia; BRNL, butanol root fraction of $N$. latifolia; ERNL, ethyl acetate
$\mathrm{CQ}$, chloroquine.

Values are mean $\pm \operatorname{SEM}(n=5)$.

$*$, Significantly different $(p<0.05)$ from negative control.

$* *$, Significantly different $(p<0.05)$ from $C Q$. 
TABLE 2: Curative activity of Nauclea latifolia roots extract and fractions against Plasmodium berghei-infected mice (Rane test).

\begin{tabular}{|c|c|c|c|c|c|c|c|c|}
\hline \multirow[t]{2}{*}{ Treatment } & \multirow[t]{2}{*}{ Dose (mg/kg) } & \multicolumn{6}{|c|}{$\%$ Parasitaemia } & \multirow[t]{2}{*}{$\%$ Cure at day 4} \\
\hline & & Before treatment & Day 0 & Day 1 & Day 2 & Day 3 & Day 4 & \\
\hline Negative control & - & $14.33 \pm 0.06$ & $14.65 \pm 0.16$ & $15.75 \pm 0.58$ & $19.15 \pm 0.22$ & $21.19 \pm 0.64$ & $23.34 \pm 0.95$ & 0.00 \\
\hline ARNL & 100 & $15.21 \pm 0.56$ & $14.30 \pm 0.56$ & $11.98 \pm 0.38 *$ & $10.25 \pm 0.16^{*}$ & $7.60 \pm 0.24 *$ & $5.37 \pm 0.25^{*}$ & $77.00 *$ \\
\hline HRNL & 100 & $14.61 \pm 0.01$ & $14.23 \pm 0.30$ & $12.20 \pm 0.48^{*}$ & $11.10 \pm 0.39 *$ & $8.91 \pm 0.28 *$ & $7.71 \pm 0.21 *$ & $67.00 *$ \\
\hline ERNL & 100 & $14.87 \pm 0.45$ & $14.53 \pm 0.81$ & $13.51 \pm 0.29 *$ & $13.13 \pm 0.39 *$ & $11.81 \pm 0.45^{*}$ & $10.45 \pm 0.20 *$ & $52.23 *$ \\
\hline BRNL & 100 & $14.88 \pm 0.91$ & $14.30 \pm 0.27$ & $12.42 \pm 0.23 *$ & $11.06 \pm 0.48^{*}$ & $9.34 \pm 0.43 *$ & $8.43 \pm 0.25^{*}$ & $63.88 *$ \\
\hline $\mathrm{CQ}$ & 5 & $15.31 \pm 0.71$ & $14.21 \pm 0.45$ & $9.41 \pm 0.18 *$ & $1.83 \pm 0.93 *$ & -ve & -ve & $100.00 *$ \\
\hline
\end{tabular}

ARNL, aqueous root extract of $N$. latifolia; HRNL, $n$-hexane root fraction of $N$. latifolia; ERNL, ethyl acetate root fraction of $N$. latifolia; BRNL, butanol root fraction of $N$. Iatifolia; CQ, chloroquine.

Values are mean $\pm \operatorname{SEM}(n=3)$.

*, Significantly different $(p<0.05)$ from negative control.

ARNL, HRNL, ERNL, BRNL and CQ, used as positive control. The percentages of chemosuppression of N. latifolia root extract and fractions were in the range of $65.53 \%$ $91.32 \%$. These were statistically significant $(p<0.05)$ compared to the negative control group and comparable to that of standard drug CQ with a percentage suppression of $100 \%$.

\section{Results of evaluation of schizontocidal activity on established infection (curative test)}

The results of evaluation of curative effects of $N$. latifolia roots are presented in Table 2, which shows the percentage parasitaemia and percentage cure of ARNL, HRNL, ERNL, BRNL and CQ on the different days of treatment. These results were similar to those obtained for the suppressive test. The percentages of curative effect produced by N. latifolia root extract and fractions were in the range of $52.23 \%$ $77.00 \%$, which were statistically significant $(p<0.05)$ compared to the negative control group, which showed a daily increase in parasitaemia level.

\section{Discussion}

Malaria management, control and eradication clearly remain challenging and difficult tasks. This problem has widely been attributed to the unavailability of malaria vaccine, emergence of resistance of malaria parasite to existing antimalarial drugs and lack of newer drugs. Thus, there is need for novel, effective and safe antimalarial drugs. Natural products have contributed immensely to human healthcare. They have served and remain a rich source of novel bioactive compounds for the management of different human ailments. Nauclea latifolia is an important medicinal plant that has tremendous ethnomedicinal uses and pharmacological properties. The aqueous infusion of the roots of the plant is widely taken as an alternative medicine for the treatment of malaria in different parts of Nigeria. Thus, in this study, the antimalarial property of $N$. latifolia roots was evaluated.

To simulate the ethnomedicinal preparation for malarial remedy, the pulverised $N$. latifolia roots material was extracted with water to obtain ARNL, which was fractionated with solvents of increasing polarity to obtain $n$-hexane (HRNL), ethyl acetate (ERNL) and butanol (BRNL) root fractions of $N$. latifolia as previously described. To evaluate the antimalarial property of the various extract and fractions, the in vivo suppressive and curative antiplasmodial effects against established erythrocytic stage of mice-infective CQsensitive $P$. berghei NK-65 were investigated. In vivo models are often used in antimalarial studies because they take into consideration the possible prodrug effect and probable involvement of the immune system in combatting the parasite (Waako et al. 2005). The rodent parasite, $P$. berghei, is widely used in antimalarial drug discovery and was applied in the development of some conventional antimalarial drugs such as quinine, $C Q$, halofantrine, mefloquine and recently the artemisinin derivatives (Thomas et al. 1998; Nutham et al. 2015; Somsak, Polwiang \& Chachiyo 2016).

The results of the evaluation of suppressive property of $N$. latifolia roots are as presented in Table 1. During the 4-day early infection study, the extract and fractions of $N$. latifolia roots exerted significant suppressive antiplasmodial activities. The $n$-hexane fraction (RHNL) gave the highest activity, a 91.32\% chemosuppression. The suppressive activities of the extract and fractions, which save ERNL (65.53\% chemosuppression), were comparable to that of CQ with a percentage suppression of $100 \%$. The highest parasitaemia $(15.90 \%)$ was recorded in the negative control group, while no parasitaemia $(0 \%)$ was recorded in the positive control group, treated with CQ. The parasitaemia for the groups treated with the extract and fractions were $2.35 \%, 1.38 \%$, $5.48 \%$ and $2.46 \%$ for ARNL, HRNL, ERNL and BRNL, respectively, which were greatly lower than that in the negative control group. The decrease in parasitaemia level in the treatment groups shows that the animals responded to the treatment given and indicates that the treatments had an effect on the multiplication and erythrocyte infectivity of P. berghei parasites in mice. According to Deharo et al. (2001), in vivo antiplasmodial activity could be classified as moderate, good and very good if an extract showed percentage parasitaemia suppression equal to or greater than $50 \%$ at a dose of $500 \mathrm{mg} / \mathrm{kg}, 250 \mathrm{mg} / \mathrm{kg}$ and $100 \mathrm{mg} / \mathrm{kg}$ per day, respectively, suggesting therefore that the extract and fractions of $N$. latifolia root have very good activities.

The results of the evaluation of curative effects of $N$. latifolia roots are as presented in Table 2. Similar to their suppressive properties, the extract and fractions gave significant curative antiplasmodial activities. A daily increase in parasitaemia level was observed for the negative control group, while 
marked reductions in parasitaemia level were observed for the groups treated with the extract or fractions and CQ from day 2 of treatment. After the final treatment, the percentage cure of the extract and fractions were $77.00 \%, 67.00 \%, 52.23 \%$ and $63.88 \%$ for ARNL, HRNL, ERNL and BRNL, respectively, which were relatively lower than that in the positive control group, treated with CQ, with percentage cure of $100 \%$, indicating complete curative effect. The observed lower efficacy of the extract and fractions, when compared to $C Q$, is not uncommon with medicinal plants extracts and may in part be because of non-selectivity of the extract or slow absorption and poor bioavailability of the extracts (Adzu \& Haruna 2007).

Determination of percentage inhibition of parasite growth is regarded as the most dependable parameter in antimalarial drug discovery (Bantie et al. 2014; Mojab 2012). The extract and fractions of $N$. latifolia roots exerted significant inhibitory effects in parasite growth in both suppressive and curative assays, which signify that the plant is endowed with antimalarial property. The results further show that the $n$-hexane and butanol fractions had comparable antiplasmodial property to the crude aqueous extract. In fact, the $n$-hexane fraction showed a relatively higher suppressive effect than the aqueous extract. However, the current evidence does not suffice to speculate if this is because of an antagonistic interaction among different antiplasmodial constituents in the crude extract. A similar pattern was observed in the antiplasmodial activities of ethanolic extract and fractions of stem bark of N. latifolia reported by Ettebong et al. (2015), where the aqueous fraction had a higher suppressive effect than the crude ethanolic extract. Our results corroborate the previous findings of Benoit-Vical et al. (1998), who reported the antiplasmodial property of aqueous stem and root $N$. latifolia extracts.

Previous studies have reported the phytochemical constituents of N. latifolia roots to include alkaloids, flavonoids, phenols, tannins, terpenes, saponins, anthraquinones, reducing sugars and glycosides (Bassey \& Jude 2014; Ngo Bum et al. 2009; Okwori et al. 2008; Taïwe et al. 2011). The presence of these phytochemicals in $N$. latifolia roots could be responsible for its antimalarial activities. Although the mechanism of action of the extract and fractions used in this study has not been elucidated, they might have exerted their antiplasmodial activities either by causing red blood cell oxidation or by inhibiting protein synthesis or by other unknown mechanism. In addition, antioxidant substances have been reported to inhibit heme polymerisation (Vial 1996), a mechanistic action of the antiplasmodial activity of quinoline-containing antimalarial drugs such as CQ. Hence, the antiplasmodial property of $N$. latifolia root could be associated with its antioxidant activity as reported by Alabi et al. (2017).

\section{Conclusion}

Our results showed that the crude aqueous extract and $n$-hexane, ethyl acetate and butanol fractions of N. latifolia roots demonstrated significant antimalarial activities. The activities of the aqueous, $n$-hexane and butanol infusions were comparable to that of CQ. These findings may validate the ethnomedicinal use of $N$. latifolia roots in the treatment of malaria and suggest that roots of $N$. latifolia present a source of promising phytochemicals for the development of novel antimalarial agents. Therefore, further studies to isolate, identify, elucidate and characterise the active constituents of $N$. latifolia roots extract and fractions are recommended.

\section{Acknowledgements}

The authors are grateful to Mr Duncan A. Ota, Department of Physiology, College of Medicine of the University of Lagos (CMUL), for his assistance in the accomplishment of this project.

\section{Competing interests}

The authors declare that they have no financial or personal relationship(s) that may have inappropriately influenced them in writing this article.

\section{Author's contributions}

C.S.A., A.R.O. and H.A.B.C. are responsible for manuscript design; C.S.A., M.O.N., I.N.J. and B.D.O. for execution; C.S.A., A.R.O., M.O.N., I.N.J. and B.D.O. for interpretation; C.S.A. and A.R.O. for writing of the manuscript.

\section{Funding information}

This research received no grant or funding from any agency in the public, commercial or not-for-profit sectors.

\section{Data availability statement}

The datasets generated during this study are available from the corresponding author on request.

\section{Disclaimer}

The views and opinions expressed in this article are those of the authors and do not necessarily reflect the official policy or position of the affiliated institution of the authors.

\section{References}

Abdullahi, M., Amupitan, J.O., Oyawale, A.O., Okogun, J.I. \& Ibrahim, K., 2007, 'An ethnobotanical survey of indigenous flora for treating tuberculosis and other respiratory diseases in Niger State Nigeria', Journal of Phytomedicine and Therapeutics 12, 1-12. https://doi.org/10.4314/jopat.v12i1.41362

Abreu, P. \& Pereira, A., 1998, 'A new Indole alkaloid from Sarcocephalus latifolius', Heterocycles 48(5), 885-891. https://doi.org/10.3987/COM-97-8091

Adebowale, E.A., 1993, 'Some ethno veterinary and traditional management practices in livestock production', Proceeding of a workshop on indigenous knowledge in agriculture and development, Ibadan, pp. 24-26.

Ademola, O.A., Oluwafemi, O.O. \& Nicole, L.B., 2014, 'In vitro study on the antioxidant potentials of the leaves and fruits of Nauclea latifolia', The Scientific World Journal 23(4), 23-33

Ademola, I.O., Fagbemi, B.O. \& Idowu, S.O., 2007, 'Antihelminthic efficacy of Nauclea latifolia extract against gastrointestinal nematodes of sheep in vitro and in vivo studies', African Journal of Traditional, Complementary and Alternative Medicine 4(2), 148-156. https://doi.org/10.4314/ajtcam.v4i2.31202

Adzu, B. \& Haruna, A., 2007, 'Studies on the use of Zizyphus Spina-Christi against pain in rats and mice', African Journal of Biotechnology 6(11), 1317-1324. 
Akpanabiatu, M.I., Umoh, I.B., Udosen, E.O., Udoh, A.E. \& Edet, E.E., 2005, 'Rat serum electrolytes, lipid profile and cardiovascular activity on Nauclea latifolia leaf extract administration', Indian Journal of Clinical Biochemistry 20(2), 29-34. https://doi.org/10.1007/BF02867397

Alabi, Q.K., Olukiran, O.S., Adefisayo, M.A. \& Fadeyi, B.A., 2017, 'Effects of treatment with Nauclea latifolia root decoction on sexual behavior and reproductive functions in male rabbits', Journal of Dietary Supplements 15(5), 649-664. https:// doi.org/10.1080/19390211.2017.1380105

Alaribe, C.S., Adesegun, S., Idowu, A.O., Egere, O., Ihemedu, C., Coker, H.A. et al 2018, 'Cytoprotective, healing and anti-Helicobacter pylori activities of stem bark powder extracts and butanol fraction (BNL) of alkaloid rich Nauclea latifolia SM (Rubiaceae)', West African Journal of Pharmacy 29(1), 110-120.

Arise, R.O., Akintola, A.A., Olarinoye, J.B. \& Balogun, E.A., 2012, 'Effects of aqueous extract of nauclea latifolia stem on lipid profile and some enzymes of rat liver and kidney', International Journal of Pharmacology 8(5), 389-395. https://doi. org/10.3923/ijp.2012.389.395

Balogun, M.E., Besong, E.E., Obu, D.C., Obu, M.S.U. \& Djobissie, S.F.A., 2016, 'Nauclea latifolia: A medicinal, economic and pharmacological review', Internationa Journal of Plant Research 6(2), 34-52.

Bantie, L., Assefa, S., Teklehaimanot, T. \& Engidawork, E., 2014, 'In vivo antimalaria activity of the crude leaf extract and solvent fractions of Croton macrostachyus Hocsht. (Euphorbiaceae) against Plasmodium berghei in mice', Complementry and Alternative Medicine 14, 79. https://doi.org/10.1186/1472-6882-14-79

Bassey, S.A. \& Jude, E.O., 2014, 'Phytochemical composition and antidiabetic activity of ethanol root extract of Nauclea latifolia', The Journal of Phytopharmacology $3(1), 52-56$

Benoit-Vical, F., Valentin, A., Cournac, V., Pelissier, Y., Mallie, M. \& Bastide, J.M., 1998 'In vitro antiplasmodial activity of stem and root extracts of Nauclea latifolia S.M (Rubiaceae)', Journal of Ethnopharmacology 61(3), 173-178. https://doi.org/10. 1016/S0378-8741(98)00036-1

Brown, R.T., Chapple, C.L. \& Lashford, A.G., 1977, 'Isolation of strictosidine (Isovincoside) Lactam from Nauclea latifolia', Phytochemistry 16(10), 1619-1620. https://doi.org/10.1016/0031-9422(77)84047-8

Deharo, E., Bourdy, G., Quenevo, C., Munoz, V., Ruiz, G. \& Sauvain, M., 2001, 'A search for national bioactive compounds in Bolivia through a multidisciplinary approach. Part V. Evaluation of the antimalarial activity of plants used by the Tecana Indians', Journal of Ethnopharmacology 77(1), 91-98. https://doi.org/10.1016/S03788741(01)00270-7

Duke, J.A., 2008, Ethnobotanical uses of Nauclea latifolia, phytochemical and ethnobotanical databases, viewed 03 May 2018, from https://www. bartleby.com

Elujoba, A.A., 1995, 'Female infertility in the hands of traditional birth attendants in South-West Nigeria', Fitoterapia 66(3), 239-248.

Ettebong, E.O., Ubulom, P.M., Ekpenyong, C.E., Ekong U.S., Akpan, O.E. \& Tambari, V., 2015, 'In vivo antiplasmodial activities of Nauclea latifolia', Asian Journal of Medical Sciences 6(3), 6-11. https://doi.org/10.3126/ajms.v6i3.11361

Gidado, A., Ameh, D.A. \& Atawodi, S.E., 2005, 'Effect of Nauclea latifolia leaves aqueous extracts on blood glucose levels of normal and alloxan-induced diabetic rats', African Journal of Biotechnology 4(1), 91-93.

Knight, D.J. \& Peters, W., 1980, 'The antimalarial action of N-benzyloxy dihydrotriazines. The action of cycloguanil (BRL50216) against rodent malaria and studies on its mode of action', Annals of Tropical Medicine \& Parasitology 74(4), 393-404. https://doi.org/10.1080/00034983.1980.11687360

Lamidi, M.E, Oliver, R., Faurel, L., Debrauwer, L., Nze, E. \& Balandsard, G., 1995 'Quinovic acid glycosides from Nauclea diderichic', Planta Medica 61(3), 280-281. https://doi.org/10.1055/s-2006-958075
Maikai, V.A. \& Kobo, P.I., 2008, 'Preliminary studies on the in vitro antitrypanosomal activity of aqueous and methanolic crude extracts of stem bark of Nauclea Latifolia on Trypanosoma congolense', Journal of Medicinal Plants 2(6), 115-118.

Maitera, O.N., Khan, M.E. \& James, T.F., 2011, 'Phytochemical analysis and the chemotherapeutics of leaves and stembark of Nauclea latifolia grown in Hong, Adamawa State Nigeria', Asian Journal of Plant Science and Research 1(3), 16-22.

Mojab, F., 2012, 'Antimalarial natural products: A review', Avicenna Journal of Phytomedicine 2(2), 52-62.

Ngo Bum, E.N., Taiwe, G.S., Moto, F.C.O., Ngoupaye, G.T., Nkantchoua, G.C.N. Pelanken, M.M. et al., 2009, 'Anticonvulsant, anxiolytic and sedative properties of the roots of Nauclea latifolia Smith in mice', Epilepsy \& Behaviour 15(4), 434-440. https://doi.org/10.1016/j.yebeh.2009.05.014

Nutham, N., Sakulmettatham, S., Klongthacvvlay, S., Chutoam, P. \& Somsak, V., 2015, 'Protective effects of Tinospora crispa stem extract on renal damage and hemolysis during Plasmodium berghei infection in mice', Journal of Pathogens 2015, Article ID 738608, 5. https://doi.org/10.1155/2015/738608

Nworgu, Z.A.M., Owolabi, O.J. \& Atomah J.E., 2010, 'Effect of the ethanolic extract of Nauclea latifolia (family: Rubiaceae) on the isolated uterus of non-pregnant rats', International Journal of Green Pharmacy 4, 48-53. https://doi.org/10.4103/0973 8258.62162

Okwori, A.E.J., Okeke, C., Uzoechina, A., Etukudoh, N.S, Amali, M.N., Adetunji, J.A. et al., 2008, 'The antibacterial potentials of Nauclea latifolia', African Journal of Biotechnology 7(10), 1394-1399.

Onu, U., Nwiyi, P. \& Erumaka, I., 2015, 'Antiviral effects of Nauclea latifolia on Newcastle disease virus (NDV)', Sky Journal of Microbiology Research 3(1), 001-005.

Owolabi, O.J, Nworgu, Z.A.M. \& Odushu, K., 2010, 'Antidiarrhoeal evaluation of the ethanol extract of Nauclea latifolia root bark', Methods and Findings in Experimental and Clinical Pharmacology 32(8), 551-555. https://doi.org/10.1358/ $\mathrm{mf}$.2010.32.8.1440747

Ryley, J.F. \& Peters, W., 1970, 'The antimalarial activity of some quinolone esters', Annals of Tropical Medicine \& Parasitology 64(2), 209-222. https://doi.org/10.10 80/00034983.1970.11686683

Saidu, K., Onah, J., Orisadipe, A., Olusola, A., Wambebe, C. \& Gamaniel, K., 2000 'Antiplasmodial, analgesic, and antinflammatory activities of the aqueous extract of the stem bark of Erythrina senegalensis', Journal of Ethnopharmacology 71(1-2), 275-280. https://doi.org/10.1016/S0378-8741(00)00188-4

Somsak, V., Polwiang, N. \& Chachiyo, S., 2016, 'In vivo antimalarial activity of Annono muricata leaf extract in mice infected with Plasmodium berghei', Journal of Pathogens 2016, Article ID 3264070, 5. https://doi.org/10.1155/2016/3264070

Taïwe, G.S., Ngo Bum, E., Talla, E., Dimo, T., Weiss, N., Sidiki, N. et al., 2011, 'Antipyretic and antinociceptive effects of Nauclea latifolia root decoction and possible mechanisms of action', Pharmaceutical Biology 49(1), 15-25. https://doi.org/10.3 109/13880209.2010.492479

Thomas, A.M., van der Wel, A.M., Thomas, A.W., Janse, C.J. \& Waters, A.P., 1998 'Transfection systems for animal models of malaria', Parasitology Today 14(6), 248-249. https://doi.org/10.1016/S0169-4758(98)01248-4

Vial, H., 1996, 'Recent developments and rationale towards new strategies for malarial chemotherapy', Parasite 3(1), 3-23. https://doi.org/10.1051/parasite/1996031003

Waako, P.J., Gumede, B., Smith, P. \& Folb, P.I., 2005, 'The in vitro and in vivo antimalaria activity of Cardiospermum halicacabum and Momordica foetida', Journal of Ethnopharmacology 99(1), 137-143. https://doi.org/10.1016/j.jep.2005.02.017

Walsh, F., 2015, 'Malaria vaccine gets "green light"', BBC News Online, viewed 04 May 2018, from https://www.bbc.com/news/health-33641939.

World Health Organization (WHO), 2016, World malaria report, 2016, World Health Organization, Geneva.

World Health Organization (WHO), 2012, Management of severe malaria: A practical handbook, 3rd edn., World Health Organization, Geneva. 